\title{
Access, Engagement, and Community Connections
}

\author{
DR. KATINA POLLOCK \\ University of Western Ontario
}

\begin{abstract}
This paper explores access to, and engagement of, marginalized communities in the public education system. It begins by interrogating the meaning of access and engagement in education from a social justice position, and then turns to challenges that practitioners experience as they attempt to help marginalized groups gain access to education. Possibilities are suggested for overcoming and addressing such challenges. The article then reconceptualizes student engagement in a way that challenges educators to rethink how they currently understand student engagement, followed by a discussion about how to connect with school communities as a way to encourage student and community access and engagement in education. Lastly, strategies for building community relationships are presented.
\end{abstract}

\section{Introduction}

During winter 2012, Western University, in partnership with the Thames Valley District School Board (TVDSB), organized a conference entitled, Making Connections: Exploring Equity and Engagement in Education. This conference was part of a larger knowledge mobilization and network initiative entitled, Understanding Equity and Engagement. It focused on sharing recent research findings on inclusive practices in education, and engaging participants in discussions on how to disseminate and use these findings to create greater equity within schools, increase student engagement, and improve teaching and learning. Internationally renowned scholars, Christine Sleeter and Rodney Hopson, worked with educators from TVDSB as they interrogated various problems of practice, such as how to encourage First Nations/Métis and indigenous students to attend school. While the conference focus was on engagement, much of the discussion focused on how to give marginalized groups access to education, and how to engage them. Some practitioners in the sessions spoke about how they have had meaningful interactions with marginalized groups and students. Other practitioners related how they struggled to provide access to these same individuals. They found that marginalized groups frequently rebuffed their attempts to communicate and interact with them. At one point, some of the struggling 
practitioners began asking those who were able to interact with the marginalized groups what they did to support access to education, and how to engage them. As a facilitator, it became clear to me that the group was wrestling with two ideas: access and engagement.

While access and engagement are related terms, they do not mean the same thing. Access can be understood as a noun: "the right to obtain or make use of or take advantage of something" or as a verb: "to make contact with or gain access to" (Access, 2012). In a public schooling context this could mean being able to obtain and make use of appropriate curricular programming and services. Engagement, on the other hand, can be understood as a noun that refers to "participation, involvement" or "the act of sharing in the activities of a group" (Engagement, 2012). Again, in the context of public education, students may have access to education programs and services, but may be unengaged or disengaged for a number of reasons. On the other hand, some groups of students or individuals also may want to be engaged in some type of formal schooling, but struggle with different forms of access. In order to attend to many of the social justice and equity issues students from marginalized groups encounter when trying to receive a formal education, it is not enough to focus on just engagement or access. The interplay of these two processes may challenge some groups of students and well-intentioned educators. For example, in the conference dialogues, participants presented many problems of practice that centred around the following questions: how do we help marginalized groups get access to education they require? What can we do to get parents and students appropriately engaged in the education process? What are some of the strategies that people have tried? What worked?

In an attempt to provide clarification and answers to the educators' questions, this paper explores access to, and engagement of, marginalized communities in the public education system. The paper begins by interrogating the meaning of access and engagement in education from a social justice position. It then turns to challenges that practitioners experience as they attempt to help marginalized groups gain access to education, and suggests possibilities for overcoming and addressing such challenges. The paper then reconceptualizes student engagement in a way that challenges educators to rethink how they currently understand student engagement, followed by a discussion about how to connect with school communities as a way to encourage student and community access and engagement in education. The article closes with some strategies for building community connections. 


\section{Issues of Access to Education}

One way to get closer to understanding how to support access and engagement is to first ask what we know about issues of access to education in relation to marginalized groups. Access to education can be understood in terms of physical, procedural, social, cultural, economic, curricular, teaching and learning approaches to name a few (Aynon, 1980, 1981; DiMaggio, 1982; Guo, 2006; Howard \& Lipinoga, 2010; Lin, 1999; Monkman, Ronald, \& Therament, 2005; Plata-Potter \& De Guzman, 2012; Richards \& Scott, 2009; Tuters, 2009). Some of these are integrally related to one another, while others are not.

Geography may influence access to public education and education programs and services, especially for students in rural settings. Significant evidence suggests that students from rural regions tend to have greater difficulty accessing educational programs and services (Boone \& Keough, 1994; Dworet \& Bennett 2002; Tuters, 2009). For example, students and/or vulnerable groups who are bussed, cannot afford public transportation, or do not have family who can transport them, generally do not participate in these activities. In some jurisdictions, location of residence and access to appropriate schooling is linked to socioeconomic status. Many families are not able to live in neighbourhoods that have schools with reputations for being successful, inviting, innovative, creative, and/or possess positive school climates. On the other hand, children from mid-to high socioeconomic status have families who can afford to live within these boundaries, but they also have the resources to travel to other schools if they wish. As Davison and Hawe (2012) point out:

For many students, [the schools'] physical location erodes educational engagement via the pathway of weakening students' social support systems. The lack of public transportation makes it difficult for anyone without access to a vehicle to reach it. (p. 72)

Some vulnerable groups have more challenges with physical access to schooling than others. For example, First Nations, Métis and Inuit (FNMI) students have difficulty acquiring physical access to early childhood education (Richards \& Scott, 2009), special education (Phillips, 2010), and information technology (Rideout, 2000).

But mere physical access to schools (and programming) does not mean students will receive the education they require. Schools are part of a larger bureaucratic system that is rife 
with official and unofficial procedures and policies. Some parents and students are able to decode these policies and processes to their benefit, while others have difficulty navigating the schooling environment. For example, newcomer parents and students may have difficulty with the language employed in schools (Bermudez \& Marquez, 1996; Denessen, Bakker, \& Gierveld, 2007; Plata-Potter \& De Guzman, 2012). But even if they can speak and read English or French, they may still have difficulty deciphering the appropriate meaning from the text (Gougeon, 1993; Gaskell, 2001; Howard \& Lipinoga, 2010). These, and other parents who have difficulty reading (Wainer, 2004; Kutner, Greenberg, Jin, Boyle, Hsu, \& Dunleavy, 2007), may not be able to access formal school documents, such as report cards, notices, memos, announcements, changed guidelines, Parent-Teacher Association reports, agendas, etc. Even though some parents and students may have physical access to a school site, they may still have difficulty understanding the organizational operations of the school building and larger education system (Pettit, 1987; Guo, 2006).

School organizations consist of more than mere sets of procedures and policies; all schools contain cultural and social processes as well. Some marginalized groups and individuals may have physical access to schooling and they might understand the procedural processes associated with public education, but may still have difficulty accessing meaningful schooling experiences because of the social and cultural challenges. For a variety of reasons some groups of students are not able to understand the social and cultural norms of the school environment (Stanton-Salazar \& Dornbusch, 1995; Monkman, et al., 2005). Some would argue that this is because some students and groups of students lack the appropriate cultural and social capital required to benefit from the school environment (Bourdieu, 1984). Cultural capital can be understood as a broad range of linguistic competencies, behaviours, and particular points of reference that allow a student or group of students to take advantage of the taken-for-granted cultural practices and understandings in such a way as to benefit them (DiMaggio, 1982). Social capital can be understood as the benefits generated through social networks (Lin, 1999). For example, students with the appropriate cultural capital are able to understand the daily nuances of social interactions within the school site, and benefit from this 'insider' information. Students with strong social capital will rely on the connections they have through their network of peers and family to help them navigate the education system. In this case, particular ways of acting and interacting, secure access to a meaningful education. Those students whose social and cultural 
capital matches that of the local school environment will have access to more meaningful educational opportunities than students who do not have the appropriate social and cultural capital, because they "get what is going on." On the other hand, groups of students come to school prepared to engage in the learning process, but have difficulty accessing many of the more subtle messages and meanings in school contexts, because they understand the world in very different ways (Aynon, 1980, 1981).

Students need to have access to schooling before there is any engagement. A starting point for educators who wish to support students' access to schooling is to reflect on some of the access issues that might exist for their students. Some helpful questions that can assist in the reflection process are included here.

\section{Physical Access}

Are there any students who have issues with physically getting to school? How would you know this? What would be some of the signs that a student is struggling getting to school or participating in particular programs? Has there been an absenteeism issue? Has there been a discussion about this issue with the student? What are some strategies that teachers and/or schools can employ to help overcome this challenge?

\section{Procedural Access}

What do you know about your students' background? What languages are spoken at home? What are some indications that students and/or parents are struggling with bureaucratic issues? Are some students excluded from programs that could be central to their learning? Do parents fail to attend important meetings and activities? Has someone from the education system (teacher, principal) attempted to make contact with parents and/or students outside the traditional approach, for example, participate in a home visit?

\section{Cultural and Social Processes}

What are some indications that students are struggling with social interactions at school? Have you witnessed or experienced unusual exchanges and interactions with the student? In group interactions, have you observed students not laughing at jokes or understanding 'common 
sense' statements? Have you thought about what students need to know to interact with others? Does the student have a network of friends or does he/she appear to be alone most of the time?

\section{Curriculum and Pedagogical Practices}

Have you taken the time to consider lesson content? What are some of the assumptions that are embedded within the lessons? How would you know if you were excluding a student or a group of students? Is there a safe environment that allows students to convey to you that they feel excluded? Do you know your students well enough to represent their lives within the curriculum and pedagogical practices?

For educators working towards a more socially just and equitable education for all students, even if all possible barriers to accessing education were removed, there is still the issue of engaging students.

\section{Student Engagement}

Engagement is a much contested and researched topic. It spans many research fields such as psychology (Mauno, Kinnunen, \& Ruokolainen, 2006), counseling psychology (Avery, McKay, \& Wilson, 2007; Neufeld et al., 2006), work and employment (Brown, 1996; Csikszentmihalyi, 1990; McFadden \& Munns, 2007), human resources (Murray, MacTavish, and Kolb, 2006), business (Gibbons, 2006; Greenwood, 2007), social work (Nagda \& Zuniga, 2003), and there is no agreement on its meaning. One common way of understanding school engagement is to look at it in behavioural, cognitive, and emotional terms (Fredricks, Blumenfeld, \& Paris, 2004). Behavioural engagement draws on the idea of participation where the individual is involved in particular activities considered crucial for achieving some positive outcome. In education, behavioural engagement could be participation in some academic activity that is perceived as beneficial for a successful academic outcome. Emotional engagement includes both positive and negative reactions that are presumed "to create ties to an institution and influence willingness to do the work" (Fredricks et al., 2004, p. 60). In schools, for example, it can be the positive and negative reactions students have to teachers. Cognitive engagement, on the other hand, builds on the idea of investment. "It incorporates thoughtfulness and willingness to exert the effort necessary to comprehend complex ideas and master difficult skills" (Fredricks 
et al., 2004, p. 60). Students who are cognitively engaged may be described as exerting more mental effort, creating more connections among ideas, and achieving greater understanding of ideas (Weinstein \& Mayer, 1986).

Understanding student engagement through behavioral, cognitive, and emotional terms, as just described, assumes that engagement has a particular outcome. In this regard, student success is determined by such things as the outcomes on provincial standardized tests. This perception of engagement as a means used to produce a specific outcome is common. The business literature contains many examples of using engagement as a strategy to meet some desired outcome or output as well (Gibbons, 2006; Greenwood, 2007). However, there are other more helpful ways to think about student engagement. Critical researchers have considered a different notion of engagement (Portelli, 2005; McMahon \& Portelli, 2004; Vibert \& Shields, 2003). Their research demonstrates that some individuals may be provided with an opportunity to engage, and choose to disengage or be merely unengaged. In situations where access is not an issue, but students are not engaged, educators need to ask why. Most approaches to engagement do not consider power relations. For some students, particularly those from marginalized groups, the only way they can exert some form of power is to choose to engage or not to engage, and if they choose to engage, how they go about it (Kohl, 1992). For example, some forms of engagement are preferred over others. Students who engage in schooling by critiquing the education system and problematizing practices may be viewed less favorably than students who are compliant.

In addition to being considered an outcome, engagement can also be considered as a way of being. More than a set of skills, it also includes the values and beliefs that influence decisionmaking (Portelli, 2005). Some students may believe that engaging in a particular expected way may symbolize rejection of their own culture or worldview, assimilation into a way of life that they reject, or giving in to those who have historically oppressed them (Ogbu \& Simons, 1998). For this reason, some students may choose not to engage in the schooling process. If they do choose to engage, they do so in a way that is not considered acceptable by the establishment or if they have figured out the system, they engage with enough conformity that those they encounter do not realize that their actions are not genuine.

So what does this mean for well-intentioned equity minded educators? One way to unpack this question is to ask, as an educator, what does student engagement mean? Does it 
mean engagement for a particular outcome or is it a way of life? Both ways of considering student engagement can be problematic for different reasons. Student engagement as an outcome for narrowly defined achievement on standardized tests is problematic for many groups of marginalized students (Christensen, 2000), because some of the knowledge and skills valued in their lives are not recognized in school and on tests, and some of the knowledge they are expected to learn is ill-suited for students' current life experience (Cherubini \& Hodson, 2008). The way in which some knowledge is valued over other knowledge, occurs routinely for marginalized groups who have been colonized. In many schools history is taught from a colonialist perspective. For example, it frequently does not take into account the history of Aboriginal people. Ryan (2006) describes how a local politician from a northern Innu community approached a principal of a local public school in Canada to complain about curriculum taught in the geography classes. The text used in the course explained in great detail the border between Quebec and Newfoundland and Labrador.

The young man pointed out that the Innu do not acknowledge this border. For them, Innu land - which they call Netissinan - extends from Labrador well into Québec. Their belief is that this land has been theirs to live and hunt in from time immemorial and that no borders cut across it. The principal listened to the young man's explanation and protests, but in the end declined to accept his argument. He took no steps to include the Innu version in geography classes or to change or drop the text. (Ryan, 2006, p. 22)

Perceiving engagement as a way of life can be problematic, because the structure of the current education does not support engagement with students who are interested in education as more than narrowly defined outcomes. Working towards a more socially just and equitable education system requires educators to consider how they understand student engagement and the competing purposes of education, and work within these different understandings. In trying to navigate between different purposes of education, many conference participants recognized that one place to begin was establishing relationships with communities.

Making connections to community can be considered one way to support, encourage, and increase access to, and meaningful engagement with, public education, because individual students do not exist in a vacuum; they are often a part of multiple communities and larger 
family groupings. Their local neighbourhoods can be a source of their peer groups and social networks. Others are part of various religious and cultural affiliations. Connections to these family, friends, and religious and/or cultural organizations can create various networks of which individual students can be a part. By making connections to communities, the school is tapping into existing networks that can work collectively together, to make public education a more integral part of students' lives.

\section{Connecting to Community(ies): Challenges and Strategies}

One approach to facilitating access to education and promoting student engagement as a way of being, is through connections to communities that schools serve. Community connections can be "connections between schools and community individuals, organizations, and businesses that are forged to promote students' social, emotional, physical, and intellectual development" (Sanders, 2001, p. 20). These connections can best be described as collaborative relationships with meaningful communication, where various organizations, institutions, and individuals, engage in a process that allows all involved to work towards mutual, equitable goals and/or outcomes.

Establishing meaningful connections, however, is easier said than done. Often, the lack of parent and community involvement has been blamed on the parents, when there seems to be "little understanding that the school itself might have things to learn from the parents, or that learning these things might help the school in its instructional mission” (Kugler \& Flessa, 2007, p. 19), or their involvement is often as "audience, spectator, fundraiser, or organizer" (Ciuffetelli-Parker, Grenville \& Flessa, 2011, p. 146). While there is a growing movement on the part of state and local jurisdictions to encourage connections between school and communities (e.g., the 2010 Ontario Parent Engagement Policy), the resources to do this, including hiring new staff, are still limited (Kugler \& Flessa, 2007, p. 18). In addition, educators might not have the requisite skills and knowledge to foster these meaningful connections, as principal professional development and teacher education programs have paid little attention to the importance of community building (Epstein \& Sanders, 2006), and in many cases, pay "little attention to the importance of teamwork and collaborations with parents, community partners, and others interested in students' success in school" (Ciuffetelli-Parker et al., 2011, p. 145). This also means that many educators may not understand a community's past and current experiences. For 
example, educators might not realize that parents who have experienced challenges in their own school experiences, or face ongoing economic challenges, and a wide arrange of daily stressors, may feel uncomfortable visiting their children's schools (Peterson \& Ladky, 2007).

Building and maintaining community connections may also be slow and difficult. The task is complex, so all parties have to put much time and energy (Hands, 2005) into dealing with each community's unique conditions and challenges (Riley, 2008). There is no one size fits all solution. No matter how well intentioned educators are in their attempts to connect with communities, partnering is limited if school administration does not see the value in establishing community relationships (Hands, 2005). This is significant for educators in Ontario, because of the high rate of principal turn over (Fink \& Brayman, 2006; Williams, 2001). Presently, few school administrators in Ontario stay in their current school for more than five years (Seashore Louis, Leithwood, Wahlstrom, \& Anderson, 2010). If community partnerships are complex and slowly develop over time, then these initiatives may occur with a number of school administrators as they cycle through the school. This can threaten community partnership initiatives, as the lack of support by just one administrator passing through, can easily reduce the momentum and any gains made with the partnership process.

Of all of these challenges, the most significant challenge in making connections to communities is building trust. As Emmel, Hughes, Greenhalgh, and Sales (2006) point out, "trust has been established as important...for facilitating access to hard-to-reach and vulnerable groups..." (para 2.1). Without trust, no initiative, intervention, or effort at partnering to provide access and/or student engagement, will come to fruition. But there is hope for school-community partnerships; many schools have been very successful in creating these connections and providing both access and opportunities for meaningful student engagement. And they have accomplished this through developing trusting relationships. Of the many strategies that can be employed to build trust, three general approaches, when applied simultaneously can offer assistance in this process. These include: changing the nature of school leadership, changing classroom practices, and strategically fostering closer connections to communities through the use of community gatekeepers.

School leadership can have a decisive impact on community relationships. Rather than thinking of schools as a place where students go to receive an education, where those within the building hold the necessary knowledge and skills that they will impart onto students who behave 
in a particular way, a school might better serve students by working with them and the various communities it serves. This can only happen if there is a shift in how schools are led. Working collaboratively with groups requires a sharing of power, which means a sharing of decisionmaking and responsibility. Shared leadership styles can help create cultures of communal leadership in and of itself (Ciuffetelli-Parker et al., 2011). Leading by example is one simple practice that school administrators can use (Hands, 2005). They can break down power imbalances by welcoming parents beyond their traditional roles, engaging parents in meaningful aspects of their child's education (Pushor, 2007), and making the school available for entire families, not just students who attend the school (Ciuffetelli-Parker et al., 2011).

Classroom teachers have an important role to play in community relationships. Not only can they support unconventional leaders, such as support staff and parents who are engaged in the schooling process (Ciuffetelli-Parker et al., 2011), but they can nurture the way leadership is understood at their school site. Teachers can also take a leadership role in building a supportive school climate from the classroom out. They can do this by promoting teacher excellence, collaboration, and teacher mentorship (Kugler \& Flessa, 2007). Research tells us that teachers in successful school climates care about the students, their community of colleagues, and learning together to improve students' emotional and academic success (Kugler \& Flessa, 2007). But these efforts will have limited impact on some school communities, without finding a way to connect to communities and build trust.

It is one thing to say that connections to communities need to be made; it is quite another for these connections to exist in a positive productive manner. Those who strive for a socially just and equitable education for all students, will require particular knowledge and skills to develop such strong connections. One way to make connections to vulnerable communities is through key informants or gatekeepers. Working with individuals and service providers from the voluntary and public sector (and those who may have no formal role) can help build trust. These individuals and groups are referred to as gatekeepers (Cree, Kay \& Tisdall, 2002; Emmel et al., 2006). Gatekeepers can help those in the school understand the norms and mores of community life, which can reduce suspicion and noncooperation from community members (Sixsmith, Boneham, \& Goldring, 2003, p. 588). Gatekeepers are people who can provide educators with access to the communities they want to reach, by facilitating contact with networks of socially excluded individuals and groups (Emmel et al., 2006). The key for school personnel is to find 
common ground between the gatekeeper and the school, in order to build the relationship with the gatekeeper (Emmel et al., 2006). Through the community gatekeeper, they can promote grass-roots initiatives that recognize and value community members for what they do well and love to do (Miller, Brown, \& Hopson, 2011).

\section{Conclusion}

In a socially just and equity-minded world, it is not enough to build a school, furnish it with resources and teachers, and provide guidance through curriculum policies; not all students will receive the education they need. Awareness of the interplay between issues of access to education and student engagement, need to be considered when responding to students' needs. One way to begin this process is to develop healthy, positive community connections with particular communities that have been historically ill-served in the past.

Acknowledgements

I would like to thank The Thames Valley District School Board of Ontario, Canada for its collaborative partnership. Without their involvement the Making Connections: Exploring Equity and Engagement in Education conference would not have come to fruition. I would also like to thank graduate student, Jennifer Pearce, for her help in organizing the Making Connections: Exploring Equity and Engagement in Education conference, and for providing resource support in writing this article.

Katina Pollock is an Assistant Professor in the Faculty of Education at The University of Western Ontario, Co-director of the Knowledge Network for Applied Educational Research (KNAER), and Faculty Director of the Joint Master's Leadership Program with the Thames Valley District School Board. Katina teaches in both the teacher pre-service program and at the graduate level. Her research interests include work and learning for teachers and administrators, educational leadership and policy. She is currently investigating the changing nature of school principals' work in Ontario, Canada.

\section{References}

Access. (n.d.). Retrieved from http://www.definitions.net/definition/access

Avery, D. R., McKay, P. F., \& Wilson, D. C. (2007). Engaging the aging workforce: The relationship between perceived age similarity, satisfaction with coworkers, and employee engagement. Journal of Applied Psychology, 92(6), 1542-1556.

Aynon, J. (1980). Social class and the hidden curriculum of work. Journal of Education, 162(1), 67-92.

Aynon, J. (1981). Social class and school knowledge. Curriculum Inquiry, 11(1), 3-42.

Bermudez, A., \& Marquez, J. (1996). An examination of a four-way collaborative to increase 
parental involvement in schools. The Journal of Educational Issues of Language Minority Students, 16(6), 1-16.

Boone, W., \& Keough, E. (1994). The challenge of providing equality of education opportunities for secondary students in small schools in rural Newfoundland and coastal Labrador. Distance! Quelle Distance? Résumé des communications/Abstracts. Ottawa, ON: Canadian Association for Distance Education.

Bourdieu, P. (1984). Distinction: A social critique of the judgement of taste. Cambridge, MA: Harvard University Press.

Brown, S. P. (1996). A meta-analysis and review of organizational research on job involvement. Psychological Bulletin, 120, 235-255.

Cherubini, L., \& Hodson, J. (2008). Ontario Ministry of Education policy and Aboriginal learners' epistemologies: A fundamental disconnect. Canadian Journal of Educational Administration and Policy, 79. Retrieved from https://www.umanitoba.ca/publications/cjeap/articles/cherubini_hodson.html

Christensen, L. (2000). Reading, writing, and rising up: Teaching about social justice and the power of the written word. Milwaukee, WI: Rethinking Schools.

Ciuffetelli-Parker, D., Grenville, H., \& Flessa, J. (2011). Case studies of school community and climate: Success narratives of schools in challenging circumstances. The School Community Journal, 21(1), 129-250.

Cree, V., Kay, H., \& Tisdall, K. (2002). Research with children: Sharing the dilemmas. Child \& Family Social Work, 7(1), 47-56.

Csikszentmihalyi, M. (1990). Flow: The psychology of optimal experience. New York, NY: Harper.

Davison, C., \& Hawe, P. (2012). School engagement among Aboriginal students in Northern Canada: Perspectives from activity settings theory. Journal of Schools Health, 82(2), 6574.

Denessen, E., Bakker, J., \& Gierveld, M. (2007). Multi-ethnic schools' parental involvement policies and practices. School Community Journal, 17(2), 27-44.

DiMaggio, P. (1982). Cultural capital and schooling success: The impact of status culture participation on the grades of U.S. high school students. American Sociological Review, 47, 189-201.

Dworet, D., \& Bennett, S. (2002). A view from the north: Special Education in Canada. Teaching Exceptional Children, 34(5), 22-29.

Emmel, N., Hughes, K., Greenhalgh, J., \& Sales, A. (2006). Accessing socially-excluded people: Trust and the gatekeeper in the researcher-participant relationship. Sociological Research Online, 12(2). Retrieved from http://www.socresonline.org.uk/12/2/emmel.html

Engagement. (n.d.). Definitions.net. Retrieved from http://www.definitions.net/definition/engagement

Epstein, J. L., \& Sanders, M.G. (2006). Prospects for change: Preparing educators for school, family, and community partnerships. Peabody Journal of Education, 81(2), 81-120.

Fink, D., \& Brayman, C. (2006). School leadership succession and the challenges of change. Educational Administration Quarterly, 42, 62-89.

Fredricks, J. A., Blumenfeld, P. C., \& Paris, A. H. (2004). School engagement: Potential of the concept, state of the evidence. Review of Educational Research, 74(1), 59-109.

Gaskell, J. (2001). The "public" in public schools: A school board debate. Canadian Journal of Education, 26, 19-36. 
Access, Engagement, and Community Connections

Gibbons, J. (2006). Employee engagement: A review of current research and its implications. Ottawa: The Conference Board of Canada.

Gougeon, T. (1993). Urban schools and immigrant families: Teacher perspectives. Urban Review, 25, 251-287.

Greenwood, M. (2007). Stakeholder engagement: Beyond the myth of corporate responsibility. Journal of Business Ethics, 74, 315-327.

Guo, Y. (2006). "Why didn't they show up?" Rethinking ESL parent involvement in K-12 education. TESL Canada Journal, 81(1), 80-95.

Hands, C. M. (2005). It's who you know and what you know: The process of creating partnerships between schools and communities. School Community Journal, 15(2), 6384.

Howard, K. \& Lipinoga, S. (2010). Closing down openings: Pretextuality and misunderstandings in parent-teacher conferences with Mexican immigrant families. Language \& Communication, 30(1), 33-47.

Kohl, R. (1992). I won't learn from you: Thoughts on the role of assent in learning. Rethinking Schools, 7(1), 16-19.

Kugler, J., \& Flessa, J. (2007). Leadership for parent and community involvement: Lessons from recent research in Ontario. Education Today, 19(1), 16-20.

Kutner, M., Greenberg, E., Jin, Y., Boyle, B., Hsu, Y., and Dunleavy, E. (2007). Literacy in everyday life: Results from the 2003 National Assessment of Adult Literacy (NCES 2007480). Washington, DC: National Center for Education Statistics.

Lin, N. (1999). Social networks and status attainment. Annual Review of Sociology, 25, 467-487.

Mauno, S., Kinnunen, U., \& Ruokolainen, M. (2006). Job demands and resources as antecedents of work engagement: A longitudinal study. Journal of Vocational Behavior, 70, 149-171.

McFadden, M., \& Munns, G. (2007). Student engagement and the social relations of pedagogy. British Journal of Sociology of Education, 23(3), 357-366.

McMahon, B., \& Portelli, J. P. (2004). Engagement for what? Beyond popular discourses of student engagement. Leadership and Policy in Schools, 3(1), 59-76.

Miller, P., Brown, T., \& Hopson, R. (2011). Centering love, hope, and trust in the community: Transformative urban leadership informed by Paulo Freire. Urban Education, 46(5), 1078-1099.

Monkman, K., Ronald, M., \& Therament, F. D. (2005). Social and cultural capital in an urban Latino school community. Urban Education, 40(1), 4-33.

Murray, D., MacTavish, M. D., \& Kolb, J.A. (2006, February). Encouraging teacher engagement: A new approach to performance improvement in schools. Paper presented at the meeting of the Academy of Human Resource Development International Conference, Columbus, Ohio.

Nagda, B. R. A., \& Zuniga, X. (2003). Fostering meaningful racial engagement through intergroup dialogues. Group Processes and Intergroup Relations, 6(1), 111-128.

Neufeld, J. E., Rasmussen, H. N., Lopez, S. J., Ryder, J. A., Magyar-Moe, J. L., Ford, A. I., Edwards, L. M., \& Bouwkamp, J. C. (2006). The engagement model of personenvironment interaction. The Counseling Psychologist, 34(2), 245-259.

Ogbu, J., \& Simons, H. D. (1998). Voluntary and involuntary minorities: A cultural-ecological theory of school performance with some implications for Education. Anthropology and Education Quarterly, 29(2), 155-188.

Peterson, S. S., \& Ladky, M. (2007). A survey of teachers' and principals' practices and 
challenges in fostering new immigrant parent involvement. Canadian Journal of Education, 30(2), 881-910.

Pettit, D. (1987). Ethnic parents and Australian schools (NACCME Research Paper no. 7). Woden, Australia: National Advisory and Co-ordinating Committee on Multicultural Education.

Phillips, R. (2010). Forgotten and ignored: Special Education in First Nations Schools in Canada. Canadian Journal of Educational Administration and Policy, 106. Retrieved from https://www-umanitoba-ca/publications/cjeap/articles/phillips.html

Plata-Potter, S., \& De Guzman, M. (2012). Mexican immigrant families crossing the education border: A phenomenological study. Journal of Latinos and Education, 11(2), 94-106.

Portelli, J. P. (2005). What is student engagement? In W. Hare \& J. P. Portelli (Eds.), Key questions for educators (pp. 74-77). Halifax, Nova Scotia: Edphil Books.

Pushor, D. (2007). Welcoming parents: Educators as guest hosts on school landscapes. Education Canada, 47(4), 6-8.

Richards, J., \& Scott, M. (2009). Aboriginal education: Strengthening the foundations. Ottawa, ON: Canadian Policy Research Networks. Retrieved from http://cprn.org/doc.cfm?doc $=2088 \& l=e n$

Rideout, V. (2000). Public access to the Internet and the Canadian Digital Divide. The Canadian Journal of Information and Library Science, 25(2/3), 1-21.

Riley, K. (2008). Can schools successfully meet their educational aims without the clear support of their local communities? Journal of Educational Change 9(3), 311-316.

Ryan, J. (2006). Inclusive leadership. San Francisco, CA: Jossey-Bass.

Sanders, M. G. (2001). The role of "community" in comprehensive school, family, and community programs. The Elementary School Journal, 102(1), 19-34.

Seashore Louis, K., Leithwood, K., Wahlstrom, K., \& Anderson, S. E. (2010). Learning from leadership: Investigating the links to improved student learning. Minnesota: The Center for Applied Research and Educational Improvement.

Sixsmith, J., Boneham, M., \& Goldring, J. (2003). Accessing the community: Gaining insider perspectives from the outside. Qualitative Health Research, 13(4), 578-589.

Stanton-Salazar, R., \& Dornbusch, S. (1995). Social capital and the reproduction of inequality: Information networks among Mexican-origin high school students. Sociology of Education, 68(2), 116-135.

Tuters, S. (2009). Investigating teachers understanding and responses to diversity in a rural Ontario classroom. (Unpublished master's thesis). The University of Western Ontario, London, Ontario.

Vibert, A. B., \& Shields, C. (2003). Approaches to student engagement: Does ideology matter? McGill Journal of Education, 38(2), 221-231.

Wainer, A. (2004). The new Latino south and the challenge to public education: Strategies for educators and policymakers in emerging immigrant communities. Los Angeles, CA: The Tomás Rivera Policy Institute.

Weinstein, C., \& Mayer, R. (1986). The teaching of learning strategies. In M. C. Wittrock (Ed.), Handbook of research on teaching and learning (pp. 315-327). New York, NY: MacMillian.

Williams, T. (2001). Unrecognized exodus, unaccepted accountability: The looming shortage of principals and vice principals in Ontario public school boards. Toronto, ON: Ontario Principals Council. 